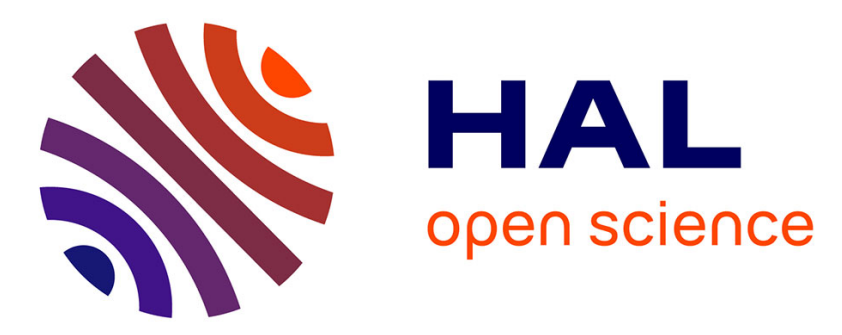

\title{
LabVIEW Interface for Controlling a Test Bench for Photovoltaic Modules and Extraction of Various Parameters
}

Abderrezak Guenounou, Ali Malek, Michel Aillerie, Achour Mahrane

\section{To cite this version:}

Abderrezak Guenounou, Ali Malek, Michel Aillerie, Achour Mahrane. LabVIEW Interface for Controlling a Test Bench for Photovoltaic Modules and Extraction of Various Parameters. International Journal of Power Electronics and Drive System (IJPEDS) , 2015, 6 (3), pp.498-508. 10.11591/ijpeds.v6i3.7827 . hal-01214767

\section{HAL Id: hal-01214767 \\ https://hal.science/hal-01214767}

Submitted on 13 Oct 2015

HAL is a multi-disciplinary open access archive for the deposit and dissemination of scientific research documents, whether they are published or not. The documents may come from teaching and research institutions in France or abroad, or from public or private research centers.
L'archive ouverte pluridisciplinaire HAL, est destinée au dépôt et à la diffusion de documents scientifiques de niveau recherche, publiés ou non, émanant des établissements d'enseignement et de recherche français ou étrangers, des laboratoires publics ou privés. 


\title{
LabVIEW Interface for Controlling a Test Bench for Photovoltaic Modules and Extraction of Various Parameters
}

\author{
Abderrezak Guenounou*, **, Ali Malek***, Michel Aillerie****, *****, Achour Mahrane* \\ * Unité de Développement des Equipements Solaires (UDES), Centre de Développement des Energies Renouvelables \\ (CDER), R.N n 11, BP 386, 42415, Bou Ismail, Tipaza, Algeria \\ ** Abou Bekr Belkaid University, Department of Physics, Tlemcen, Algeria \\ *** Centre de Développement des Energies Renouvelables (CDER), BP 62, Bouzareah, Algiers, Algeria \\ ****Université de Lorraine, LMOPS, EA 4423, 57070 Metz, France. \\ *****Centrale Supelec, LMOPS, 57070 Metz, France.
}

\begin{tabular}{l}
\hline \hline Article Info \\
\hline Article history: \\
Received Apr 16, 2015 \\
Revised Jul 27, 2015 \\
Accepted Aug 15, 2015
\end{tabular}

\section{Keyword:}

PV module

I-V Characteristic

Test bench

Electronic Load

LabVIEW GUI

Parameter Extraction

\begin{abstract}
Numerical simulation using mathematical models that take into account physical phenomena governing the operation of solar cells is a powerful tool to predict the energy production of photovoltaic modules prior to installation in a given site. These models require some parameters that manufacturers do not generally give. In addition, the availability of a tool for the control and the monitoring of performances of PV modules is of great importance for researchers, manufacturers and distributors of PV solutions. In this paper, a test and characterization protocol of PV modules is presented. It consists of an outdoor computer controlled test bench using a LabVIEW graphical interface. In addition to the measuring of the IV characteristics, it provides all the parameters of PV modules with the possibility to display and print a detailed report for each test. After the presentation of the test bench and the developed graphical interface, the obtained results based on an experimental example are presented.
\end{abstract}

Copyright (C) 2015 Institute of Advanced Engineering and Science. All rights reserved.

\section{Corresponding Author:}

A. Guenounou,

Unité de Développement des Equipements Solaires (UDES),

Centre de Développement des Energies Renouvelables (CDER),

R.N n¹1, BP 386, 42415, Bou Ismail, Tipaza, Algeria.

Email: aguenounou@yahoo.fr, or, guenounou.abderrezak@udes.dz

\section{INTRODUCTION}

Industrial development and technological progress in several areas such as communication and transport is accompanied by enormous energy needs. Much of this energy is produced from fossil fuels such as oil, natural gas coal or nuclear. However, fossil energy production is highly polluting because it generates emissions of greenhouse gases and nuclear waste product requires very expensive treatments [1].

Renewable energies in general and solar photovoltaic (PV) in particular are therefore a good alternative to ensure sustainability in the global energy production with environmental protection because it is a renewable and a non-polluting energy source.

A solar PV source has long been limited to autonomous un-grid-connected applications in remote rural sites as desert lands or mountains or for nomad applications. But in the last decades, solar PV has entered into settlements with the Building Integrated Photovoltaic (BIPV) and technology of photovoltaic grid-connected systems. This has significantly increased the demand for PV modules and thus made this highly profitable market. Consequently, this phenomenon drived by the emergence of new applications of PV panels and systems, their large diffusion and a decrease of their price, has led to a large growth of the number of actors in this field, namely researchers, manufacturers and distributors. All these actors need control and test tools for PV modules on the market but also computational tools to predict the production and the 
electrical behaviour of a PV module before the installation. The tools have to take into account the solar radiation, some physical parameters as temperature, and the possible topology of the PV generator in a given site. This can be facilitated for a part by the use of physical model and numerical simulation of the operation of PV modules. Thus, upstream, new integrated tools are necessary to be developed by research teams for, downstream facilitate and optimize the conception process of new PV systems by manufacturers and distributors.

PV module manufacturers provide usually data characteristics of PV modules under Standard Test Conditions (STC), where the irradiance is $1000 \mathrm{~W} / \mathrm{m}^{2}$ and the cell temperature (Tc) is $25^{\circ} \mathrm{C}$. Some of the parameters typically provided by manufacturers are the maximum power (Pmp), the short circuit current (Isc), the open circuit voltage (Voc), the current and voltage at the maximum power point (Imp and Vmp) and the temperature coefficients for the short circuit current and open circuit voltage $\left(\alpha_{\text {Isc }}\right.$ and $\left.\beta_{\text {Voc }}\right)$.

The physical models describing the functioning of PV modules, such as the single diode model need parameters that are not given in the manufacturer's data sheets. Therefore their determination is required.

Some authors have presented an implementation of the single diode model in LabVIEW [2], [3] for simulation needs. These techniques require the introduction of model parameter values. These values vary from PV module to another and are also affected by atmospheric conditions such as temperature. Several techniques for calculating the single diode model parameters from experimental measurements of the IV characteristic are found in the literature [4].

LabVIEW software is a powerful tool for data acquisition using specially designed cards or by controlling measuring instruments [5], [6]. It is widely used in photovoltaic for the monitoring of installations for example [7].

It is ideally more convenient to have a single LabVIEW Graphical User Interface (GUI) that controls data acquisition and also performs all other operations such as parameter extraction and simulation.

Taking into account all previous considerations, we present and validate in this contribution an original and complete outdoor and computer controlled test bench via a LabVIEW GUI for researchers and professionals working in the application and development fields related to renewable energies, mainly photovoltaic. This tool allows the measurement of the I-V characteristics of PV modules and the extraction of all the working parameters and all the parameters of the physical model and the simulation of the I-V and P$\mathrm{V}$ characteristics under measurement conditions and under STC. A technical report giving all the details and all the parameters of the PV module is thus displayed and possibly printed to establish a written report.

\section{FUNDAMENTALS}

\subsection{The Basic Single Diode Physical Model}

The model used in this work is the well-known single diode model. This model perfectly describes the operation of the PV module taking into account the physical phenomena governing the operation of solar cells. It is defined by the electrical circuit of Figure 1 and by Eq. 1 [8].

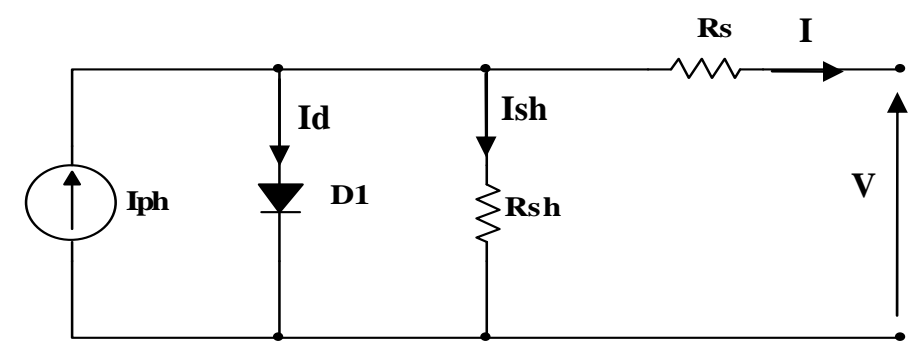

Figure 1. The Equivalent circuit diagram of a PV Module according to the single diode model

The photo-generated current Iph depends on the solar irradiance and temperature; it is represented by a current generator. The diode D1 represents the diffusion and recombination losses, the series resistance Rs represents the losses in metallic bonds and the shunt resistance Rsh all the other losses.

$$
I=I_{p h}-I_{0}\left[\exp \left(\frac{V+I R_{S}}{n \cdot N_{S} \cdot \frac{K T_{C}}{q}}\right)-1\right]-\frac{V+I R_{S}}{R_{S h}}
$$


I and $\mathrm{V}$ are the current and the output voltage of the PV module respectively. $\mathrm{I}_{0}$ is the saturation current of the diode, $\mathrm{n}$ is the ideality factor, Ns the number of solar cells in serial composing the PV module, $\mathrm{K}$ is the Boltzmann constant $\left(1.38 \times 10^{-23} \mathrm{~J} / \mathrm{K}\right), \mathrm{T}_{\mathrm{C}}$ the cell temperature and $\mathrm{q}$ the elementary charge $\left(1.6 .10^{-19}\right.$ Coulomb).

\subsection{Principles of the Parameter Extraction}

The short circuit current Isc, the open circuit voltage Voc, the maximum power Pmp, the voltage and current at the maximum power point respectively Vmp and Imp, and thus, the fill factor FF $=(\mathrm{Vmp} . \mathrm{Imp})$ / (Voc.Isc) and the efficiency $\eta$ can be easily extracted from an experimental I-V characteristic of a PV module. But for the model parameters (Iph, $\mathrm{I}_{0}, \mathrm{n}, \mathrm{Rs}, \mathrm{Rsh}$ ), numerical extraction techniques are required. The method used in this work is the numerical method with five points. It involves the numerical resolution of a system of five nonlinear equations obtained by applying Eq.1 to five points of an experimental I-V characteristic [9]. These five points (cf. Figure 2) are: the short circuit point, the open circuit point, the maximum power point and two other points $(\mathrm{V}=\mathrm{Vx}, \mathrm{I}=\mathrm{Ix})$ and $(\mathrm{V}=\mathrm{Vxx}, \mathrm{I}=\mathrm{Ixx})$ chosen so that:

$V_{X}=\frac{1}{2} V_{o c}$ and $V_{X X}=\frac{1}{2}\left(V_{o c}+V_{m p}\right)$

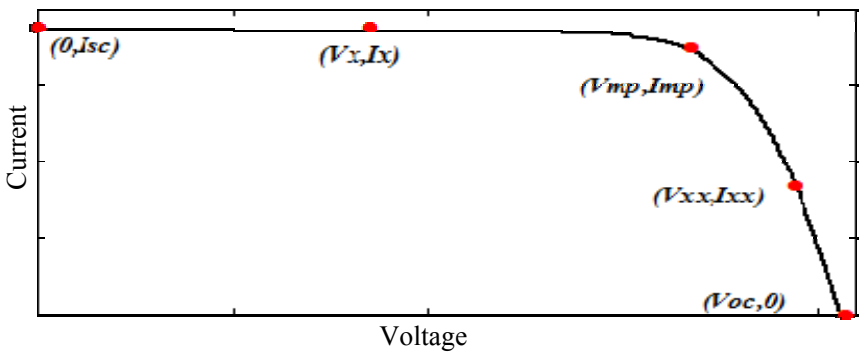

Figure 2. The five points of the IV characteristic used in the extraction method

The resolution of the system by the numerical method provides the various values of the desired parameters. The main drawback of this method is that it requires a good estimation of the initial values, which defines the accuracy of the modelling process. Indeed, a good estimation of these initial values leads to a rapid convergence of the method and, on contrary a bad one is synonymous with slow convergence or even divergence. Considering some approximations, Phang et al [10] have developed analytical expressions for the calculation of these parameters. In this present work, the results obtained from the analytical expressions of Phang are considered as initial values for the numerical method, which is based on successive approximations.

\subsection{The Translation Equations}

The plot of the I-V characteristic of a PV module using the equation of the model, Eq. 1, allows a comparison of the performance of the considered module with the standard ones, given by the manufacturer's datasheets. We have plotted this characteristic by taking into account the dependence of the parameters on the working conditions, particularly, the solar irradiance and the temperature. Information given by the manufacturers of PV modules correspond to data obtained under the Standards Test Conditions (STC) where the solar irradiance is $1000 \mathrm{~W} / \mathrm{m}^{2}$, the cell temperature is $25^{\circ} \mathrm{C}$ and the Air Mass is AM1.5. On contrary, when the parameters are extracted from experimental measurements under natural reference conditions of irradiance and cell temperature (GRef and TCRef), the following translation equations have to be used [11], [12].

$$
\begin{aligned}
& \mathrm{I}_{\mathrm{ph}}=\frac{\mathrm{G}}{\mathrm{G}_{\text {Ref }}} \cdot\left[\mathrm{I}_{\mathrm{ph}_{\text {Ref }}}+\alpha_{\mathrm{I}_{\mathrm{sc}}}\left(\mathrm{T}_{\mathrm{c}}-\mathrm{T}_{\mathrm{c}_{\mathrm{Ref}}}\right)\right] \\
& \mathrm{I}_{0}=\mathrm{I}_{0_{\text {Ref }}}\left(\frac{\mathrm{T}_{\mathrm{c}}}{\mathrm{T}_{\mathrm{c}_{\text {Ref }}}}\right)^{3} \cdot \exp \left[\frac{\mathrm{q}_{\mathrm{Eg}}}{\mathrm{nK}}\left(\frac{1}{\mathrm{~T}_{\mathrm{c}_{\text {Ref }}}}-\frac{1}{\mathrm{~T}_{\mathrm{c}}}\right)\right] \\
& \frac{\mathrm{R}_{\mathrm{sh}}}{\mathrm{R}_{\mathrm{sh}}}=\frac{\mathrm{G}_{\text {Ref }}}{\mathrm{G}}
\end{aligned}
$$




$$
\begin{aligned}
& \mathrm{I}_{\mathrm{sc}}=\mathrm{I}_{\mathrm{sc}_{\mathrm{Ref}}} \cdot \frac{\mathrm{G}}{\mathrm{G}_{\mathrm{Ref}}}+\alpha_{\mathrm{Isc}}\left(\mathrm{T}_{\mathrm{C}}-\mathrm{T}_{\mathrm{C}_{\mathrm{Ref}}}\right) \\
& \mathrm{V}_{\mathrm{oc}}=\mathrm{V}_{\mathrm{oc}_{\mathrm{Ref}}}+\mathrm{n} \frac{\mathrm{KT}_{\mathrm{C}_{\mathrm{Ref}}}}{\mathrm{q}} \ln \left(\frac{\mathrm{G}}{\mathrm{G}_{\text {Ref }}}\right)+\beta_{\mathrm{Voc}}\left(\mathrm{T}_{\mathrm{C}}-\mathrm{T}_{\mathrm{C}_{\text {Ref }}}\right)
\end{aligned}
$$

Where, $I_{\text {phRef }}, I_{S C R e f}, V_{O C R e f}, I_{O R e f}$ and $R_{\text {shRef }}$ are respectively, the solar irradiance, the cell temperature, the photocurrent, the short circuit current, the open circuit voltage, the saturation current and the shunt resistance at reference conditions, $\mathrm{G}$ and $\mathrm{Tc}$ are the irradiance ant temperature at the translated conditions which may be the STC. Eg is the Gap (eV), $\alpha_{\mathrm{Isc}}$ and $\beta_{\mathrm{Voc}}$ are, respectively, the temperature coefficients of the short circuit current and the open circuit voltage.

Two parameters remain to be translated: the series resistance Rs and the ideality factor $\mathrm{n}$. The serial resistance affects the slope of the I-V characteristic in the area where the PV module operates as a voltage generator. Its variation with the temperature is not so important to induce a significant error on the maximum power point and it is generally admitted that Rs remains constant in the standard working temperature range [11]. We consider also that the ideality factor $n$ is not affected by the temperature.

\section{THE TEST BENCH}

\subsection{Presentation}

The principle of the test bench developed in the context of this contribution is based on the block diagram of Figure 3 and the experimental realization is shown in the photo of Figure 4 . It consists of a structure on which are installed the PV modules to be tested, an electronic load built with MOSFETs, a Data Acquisition and Switch Unit (Agilent 34972A). We have developed under LabVIEW environment an interface to drive and control this test bench. The solar irradiance is measured with a pyranometer fixed on the same plane as the PV module to be tested, the temperature of the PV module is measured with a PT100 sensor bonded to its back and the current is measured with a Hall Effect sensor.

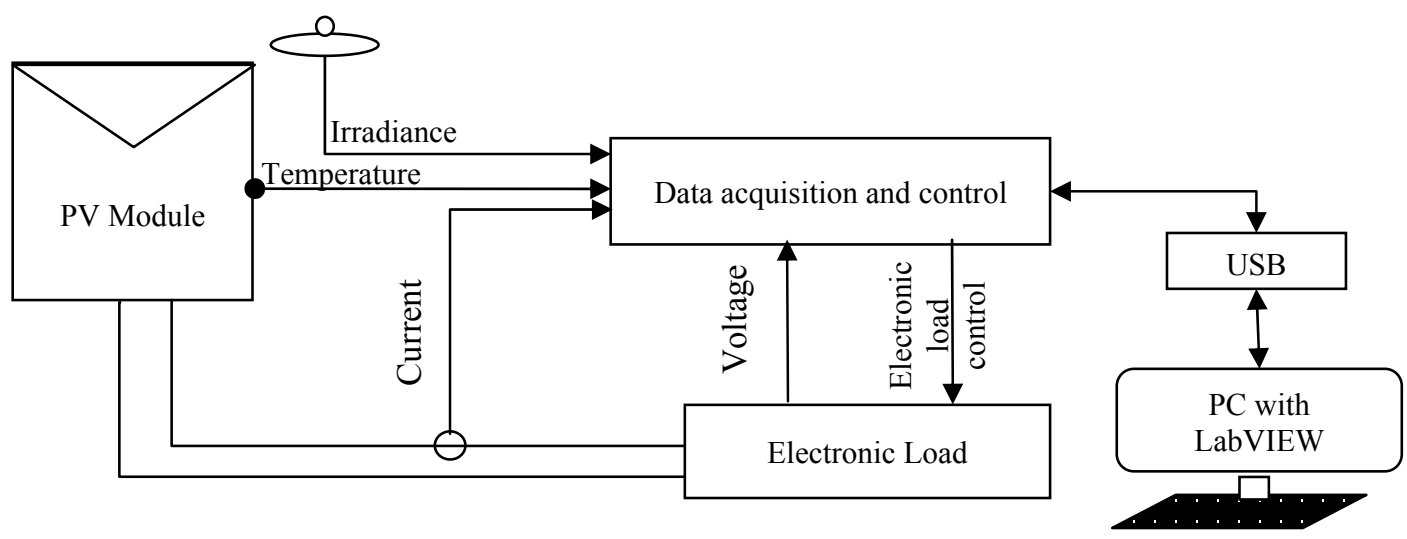

Figure 3. Block diagram of the installed test bench for PV modules 


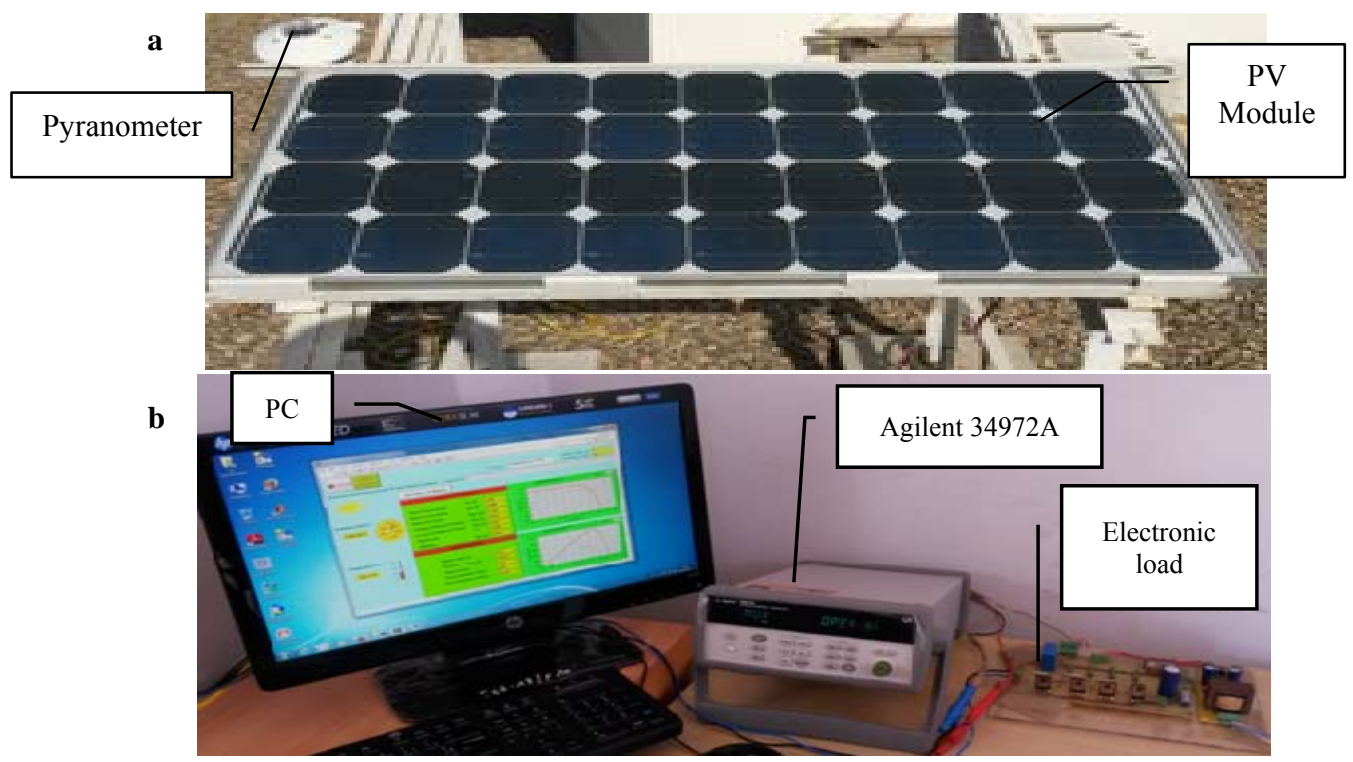

Figure 4. View of the test bench (a) PV Module with the Pyranometer, (b) Electronic load, Agilent 34972A unit and PC

\subsection{Electronic Load}

To characterize a PV module, first we must plot the current-voltage (I-V) characteristic and take up the tests conditions (solar irradiance and temperature). Therefore, the measurement must be rapid enough to avoid possible variations in solar irradiance during the whole procedure. Ideally, we should have to vary the load of the PV module from zero to infinity very rapidly, which is possible by the use of electronic loads. Several types of electronic loads have been reported in the literature. Some are based on DC / DC converters [13]; others are based on MOSFETs controlled by an Operational Amplifier [14].

The electronic load used in this contribution is based on MOSFETs whose gate voltage is controlled by a capacitor. The circuit of the electronic load previously described in [15] is shown in Figure 5. For selfconsistent explanation, we summarize the operating mode of this load. When push button $\mathrm{T}$ is closed, the capacitor $\mathrm{C}$ is charged through the resistor R1. When T is open, $\mathrm{C}$ is discharged through the resistance Req (potentiometer R and the resistance R2) inducing a variation of the gate voltage Vg of MOSFET transistors and their drain current switching from maximum (short circuit) to minimum (open circuit) values. In order to improve the response time of the test bench, the push button is replaced with a relay controlled by the LabVIEW program (see next paragraph) via the Agilent 34972 unit.

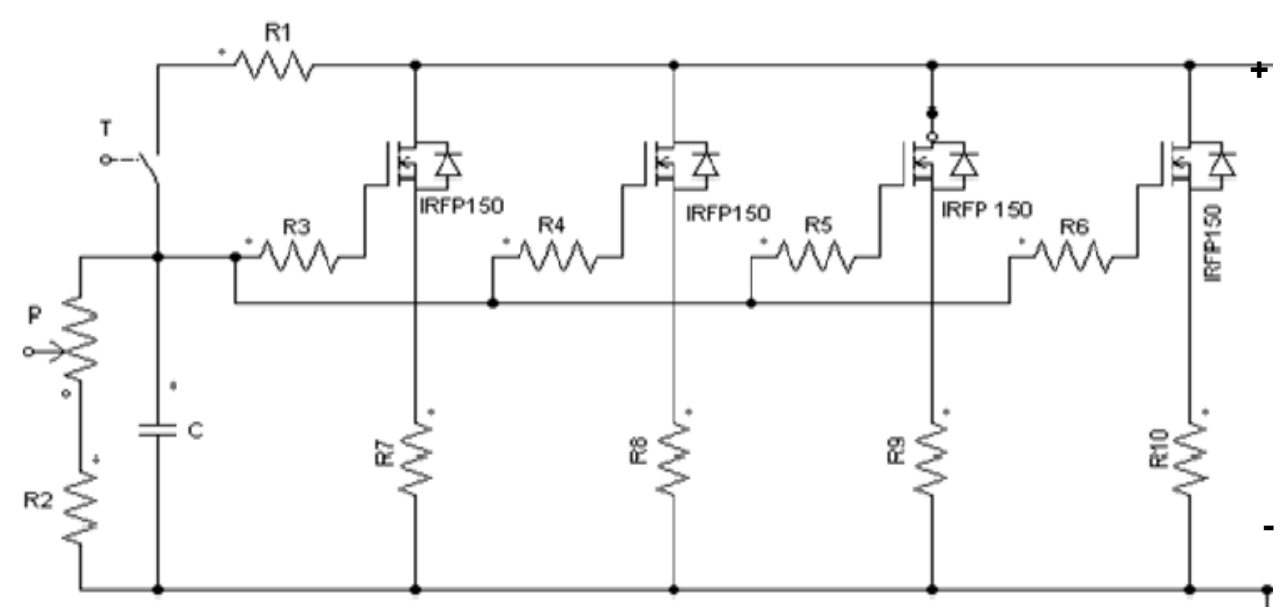

Figure 5. The electronic load circuit 


\subsection{LabVIEW Graphical User Interface}

The test bench installed is fully controlled by a dedicated program developed under LabVIEW software environment. A LabVIEW program possesses two windows. A Front Panel also called the Graphical User Interface (GUI), and a diagram that contains the program governing the GUI [5]. The two pages of the developed GUI are shown in Figure 6 and 7.

The developed program controls the electronic load and the various sensors via the Data Acquisition and Switch Unit (Agilent 34972 A). Once the current-voltage (I-V) characteristic is measured, it is displayed with the power-voltage $(\mathrm{P}-\mathrm{V})$ characteristic and all corresponding parameters on the first page of the GUI. Translation to STC is then performed to display on a second page the parameters and I-V and P-V characteristics at STC. All technical data of the PV module are displayed at the top of both pages with the dropdown list where the name of the PV module to be tested is selected. Each measured I-V characteristic is automatically saved with the irradiance and cell temperature under which it is measured in Excel file with a name consisting of the date and time of measurement.

Within this developed GUI, simulation is also performed to validate the model with the extracted parameters, and calculate the performance at STC. A test report can be printed from the GUI. It is similar to a data sheet that contains all the information on the GUI after testing a given PV module.The block diagram of Figure 8 describes the overall operation of the program governing the developed GUI and some stages of the diagram are shown in Figures 9 and 10.

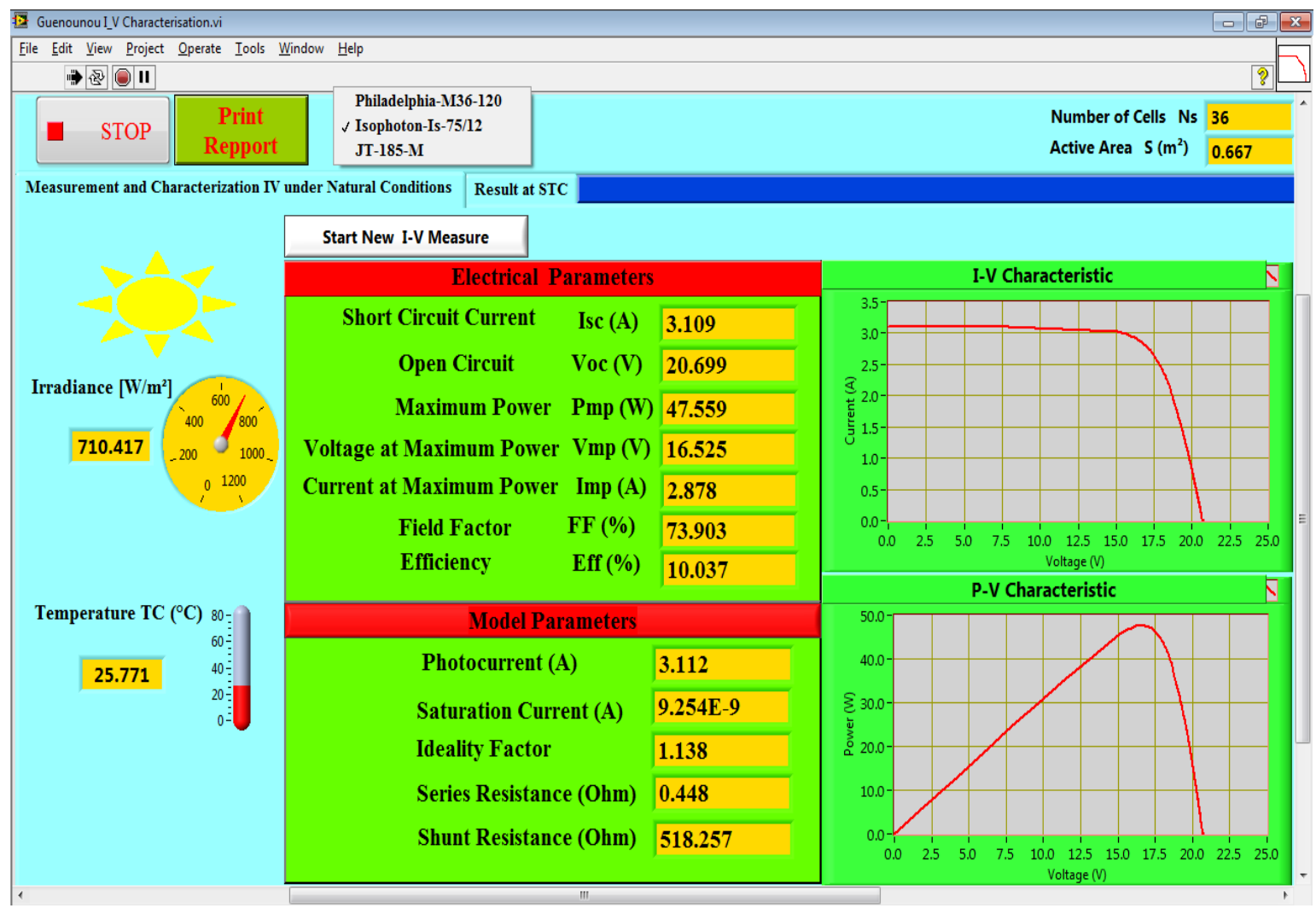

Figure 6. Developed GUI: measuring page 


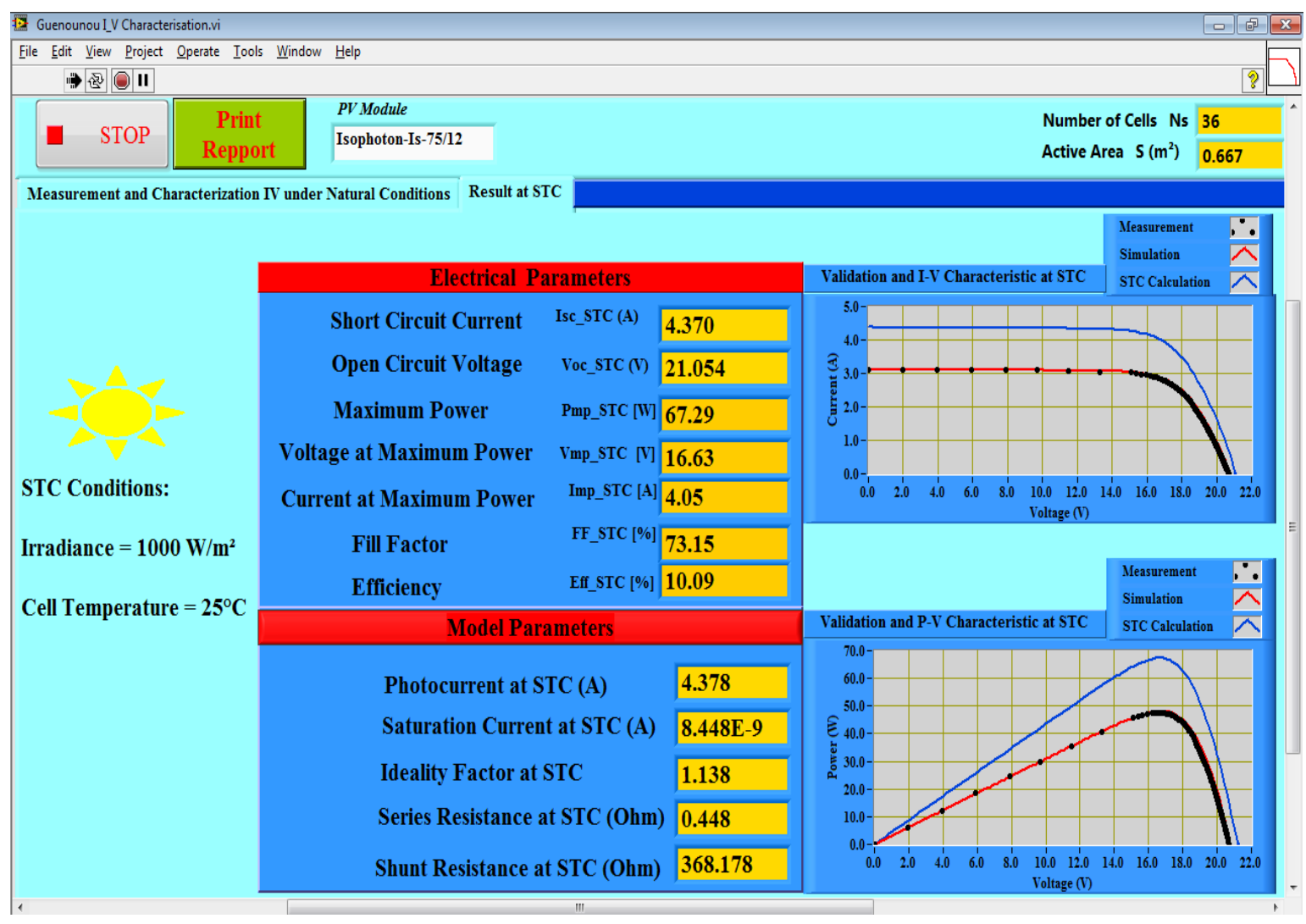

Figure 7. Developed GUI: Validation and STC Results page

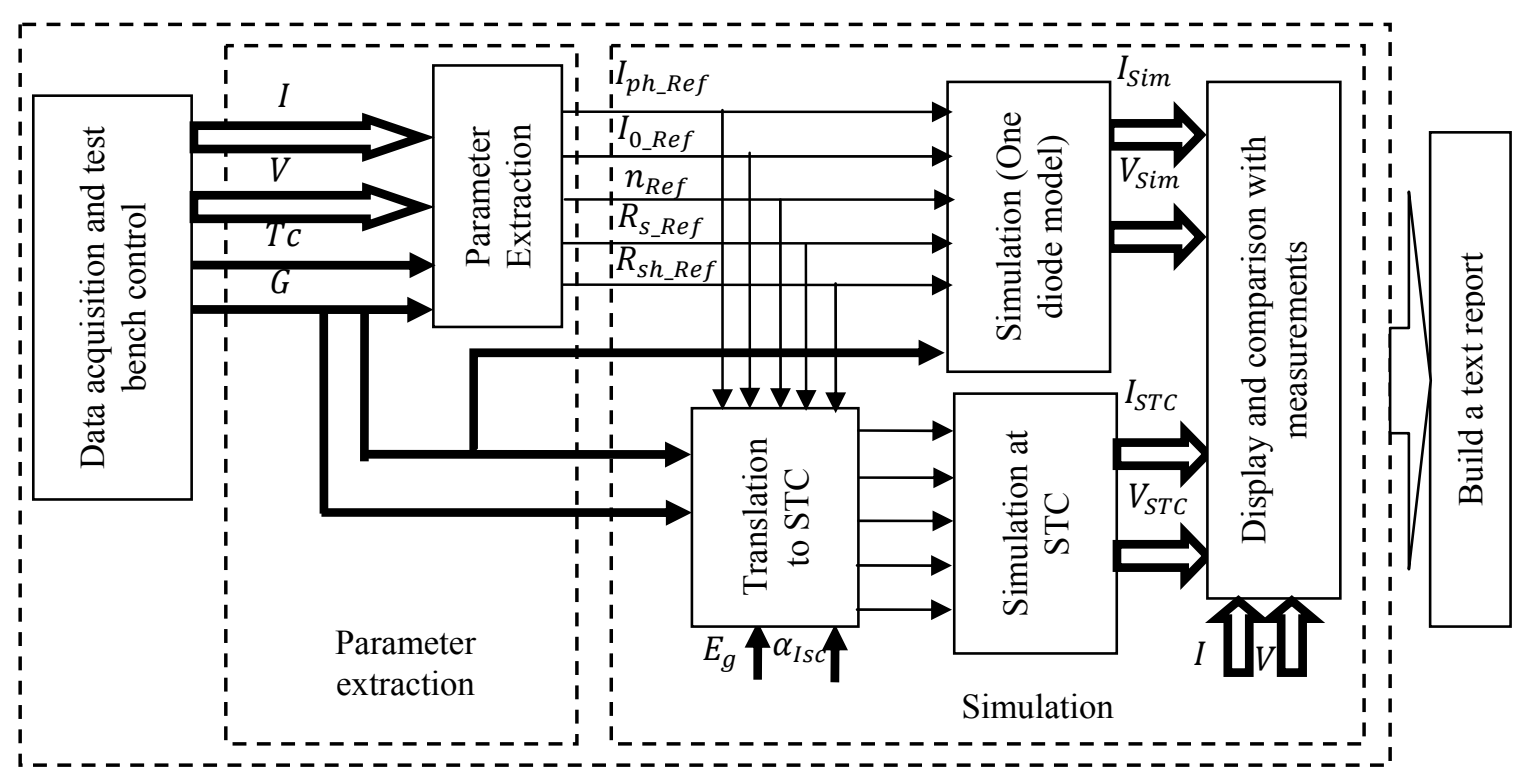

Figure 8. Block diagram showing the main tasks treated by the GUI 


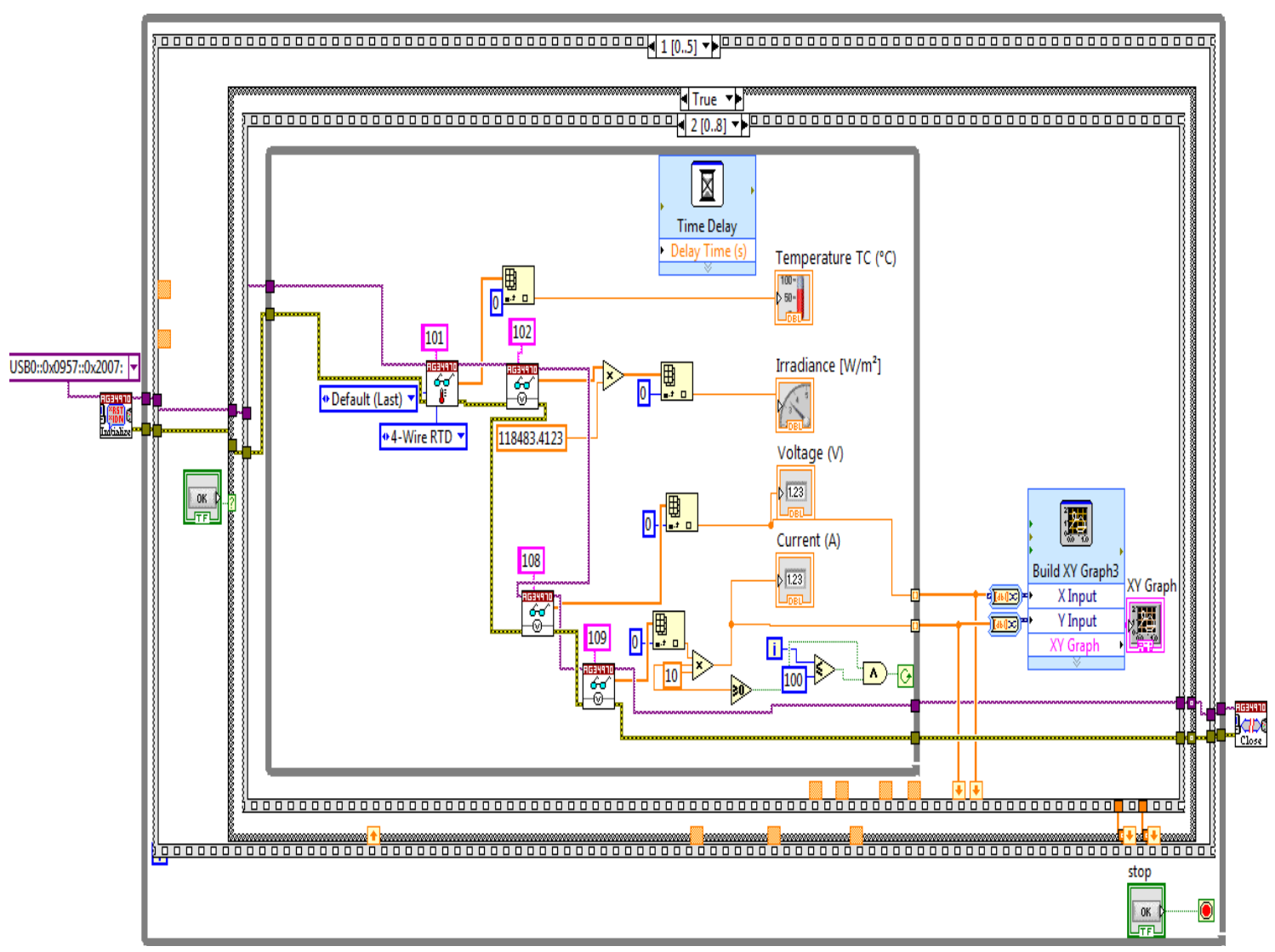

Figure 9. Diagram of the data acquisition step

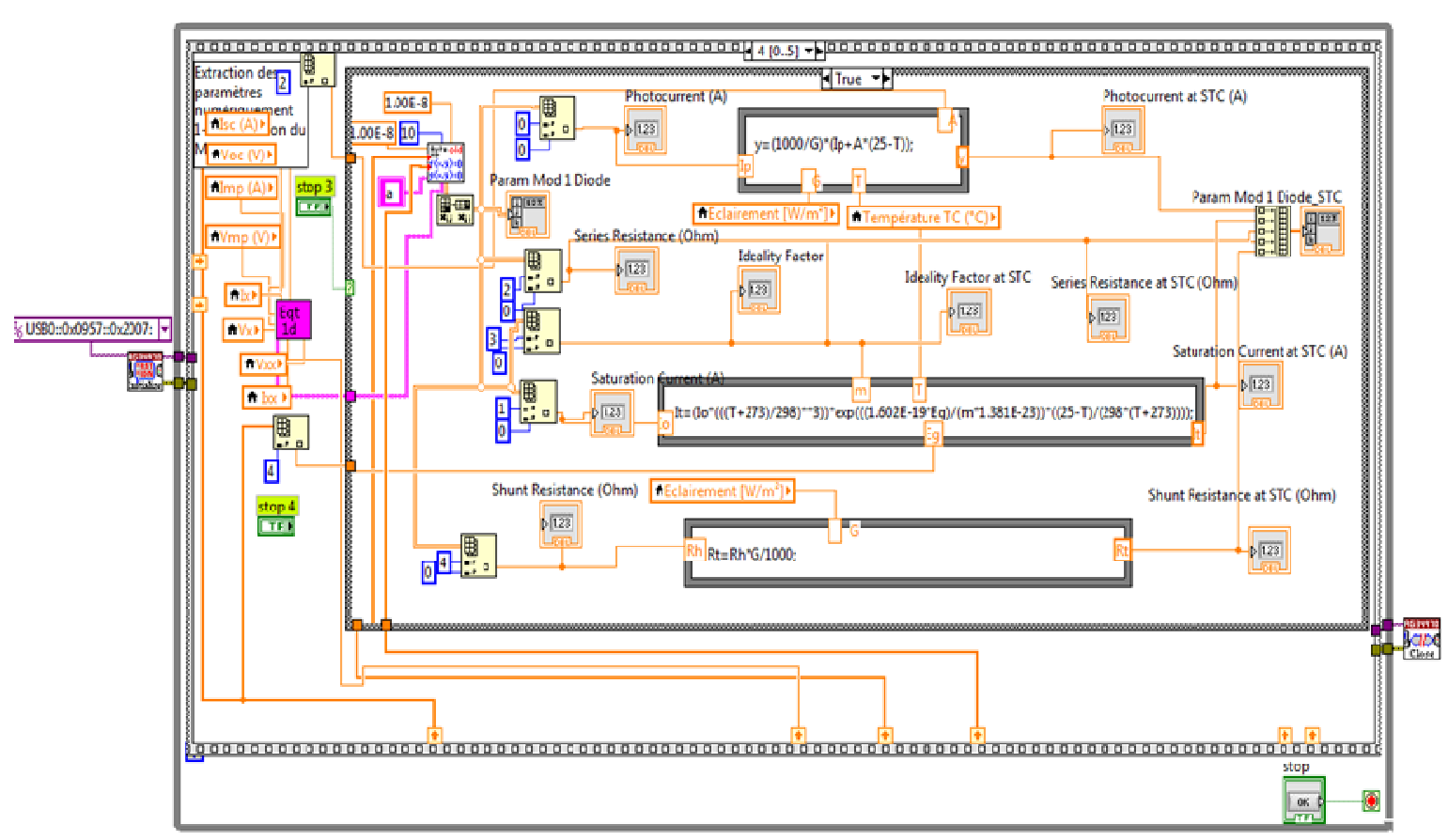

Figure 10. Diagram of the step 'Extraction of model parameters' and 'translation to STC' 


\section{VALIDATION}

We have chosen as an example study case, a single crystalline Silicon PV module with 36 cells connected in series. Several tests have been realized with the developed bench for different pairs of Irradiance and Temperature. As we explained earlier, the GUI allows the control of the bench, observing results and also the validation of these. As shown in Figure 7, there is a perfect overlap between the measured IV and PV characteristics (discontiued points) and those simulated (continued red curves). This has been verified for several tests.

For further validation, we have performed a comparison among the test results translated to STC from different Irradiance-Temperature pairs and values of the data sheet of the PV module (see Table.1). This comparison concerns the short-circuit current (Isc), open circuit voltage (Voc), maximum power (Pmax), voltage and current at the maximum power point (Imax and Vmax). As a comparison criterion, we used the relative error defined by the following expression.

$$
\Delta X / X=\frac{X_{\text {meas }}-X_{\text {datasheet }}}{X_{\text {datasheet }}} .100
$$

Where, $\mathrm{X}_{\text {meas }}$ and $\mathrm{X}_{\text {datatasheet }}$ are respectively the measured and the datasheet value of the parameter $\mathrm{X}$.

Table 1. Comparison between datasheet PV module performance and those measured at different conditions and evaluated at STC

\begin{tabular}{|c|c|c|c|c|c|c|c|c|c|}
\hline \multirow{3}{*}{$\begin{array}{l}\text { Parameter } \\
\text { (X) }\end{array}$} & \multirow{3}{*}{$\begin{array}{c}\text { Datasheet } \\
\text { values at } \\
\text { STC }\end{array}$} & \multicolumn{8}{|c|}{ Values translated to STC from different conditions of G and Tc } \\
\hline & & \multicolumn{2}{|c|}{$\begin{array}{c}\mathrm{G}=687.19 \mathrm{~W} / \mathrm{m}^{2} \\
\mathrm{Tc}=36.84^{\circ} \mathrm{C}\end{array}$} & \multicolumn{2}{|c|}{$\begin{array}{c}\mathrm{G}=722.28 \mathrm{~W} / \mathrm{m}^{2} \\
\mathrm{Tc}=37.37^{\circ} \mathrm{C}\end{array}$} & \multicolumn{2}{|c|}{$\begin{array}{c}\mathrm{G}=770.38 \mathrm{~W} / \mathrm{m}^{2} \\
\mathrm{Tc}=26.79^{\circ} \mathrm{C}\end{array}$} & \multicolumn{2}{|c|}{$\begin{array}{c}\mathrm{G}=850.97 \mathrm{~W} / \mathrm{m}^{2} \\
\mathrm{Tc}=31.88^{\circ} \mathrm{C}\end{array}$} \\
\hline & & X & $\Delta \mathrm{X} / X$ & $\mathrm{X}$ & $\Delta \mathrm{X} / X$ & X & $\Delta \mathrm{X} / \mathrm{X}$ & X & $\Delta \mathrm{X} / X$ \\
\hline $\operatorname{Pmax}(\mathrm{Wc})$ & $75 \pm 10 \%$ & 67.01 & $-10.65 \%$ & 67.41 & $-10.12 \%$ & 67.43 & $-10.09 \%$ & 67.52 & $-9.97 \%$ \\
\hline Isc (A) & 4.67 & 4.27 & $-4.72 \%$ & 4.32 & $-4.07 \%$ & 4.32 & $-3.70 \%$ & 4.38 & $-3.89 \%$ \\
\hline Voc $(V)$ & 21.6 & 20.58 & $-8.57 \%$ & 20.72 & $-7.49 \%$ & 20.80 & $-7.49 \%$ & 20.76 & $-6.21 \%$ \\
\hline $\operatorname{Imax}(\mathrm{A})$ & 4.34 & 3.98 & $-8.29 \%$ & 4.02 & $-7.37 \%$ & 3.97 & $-8.53 \%$ & 4.07 & $-6.22 \%$ \\
\hline$V \max (\mathrm{V})$ & 17.35 & 16.82 & $-3.05 \%$ & 16.77 & $-3.34 \%$ & 17.00 & $-2.02 \%$ & 16.57 & $-4.50 \%$ \\
\hline
\end{tabular}

Beyond the experimental errors, we note that each group of extracted model parameters reproduce the corresponding measured I-V characteristic in an acceptable manner. In addition, from Tables 1, the measured values are consistent with those of the datasheet of PV module if the tolerance in the given values by the manufacturer is taken into account ( $\pm 10 \%$ for the maximum power). In a similar comparison between the values of some parameters of datasheets of some PV modules and the single diode model results obtained from measurements at $850 \mathrm{~W} / \mathrm{m}^{2}$ of irradiance, Mermoud [16] found similar gaps to those in Table 1 for the same type of PV module, except for Voc where our gap is larger. That can be due to the aging of our PV module.

Thus, with this original test bench developed in this work and presented in the current contribution, researchers and professionals working in the application and development fields related to photovoltaic can easily perform a complete electrical test of commercial PV modules or panels before their use in experimental works or their implantation in new renewable electrical generators. The results are very important, as in addition to the validation of the values of the electrical parameters extracted from the commercial and/or manufacturer datasheets of the PV module under consideration, the bench based on the simple diode model provides all panel parameters, as the series resistance, the shunt resistance, the ideality factor, the saturation current and the photocurrent, not generally included in the datasheets and it realizes the full simulation of its I-V and P-V characteristics at measurement conditions and under STC.

\section{CONCLUSION}

The Grafical User Interface (GUI) presented in this paper is associated to a fairly complete test and characterization tools allowing its use by researchers and professionals working in the application and development fields related to photovoltaic. The two main objectives of this original developement are the control of an outdoor test bench for PV module and the extraction of all the electrical parameters of PV module based on the one diode model parameters. These so obtained working parameters are of prior importance. They are necessary for the implementation of the model in a simulation program and are generally not given by the manufacturer in the data sheets of PV modules. Additionally, we have implemented the function related to the simulation of the PV panel within this GUI. It is performed under

LabVIEW interface for controlling a test bench for photovoltaic modules and extraction ....(A. Guenounou) 
measurement conditions to validate the model and at standard test conditions, STC, to calculate the values of the electrical parameters of the PV module. This allows the comparison between the so-obtained experimental values with those provided by the manufacturer in the data sheet of the PV module. In this work, a special care was brought in the user interface by the association of a LabVIEW GUI offering much interactivity in the test bench allowing to easily performing complete electrical tests of various commercial PV modules or panels before their use in experimental works or their implantation in new renewable electrical generators. Finally, an experimental application, done with a commercial PV module for different pairs of irradiance and temperature illustrates this study and validates the concept and the development of the test bench and its associated GUI.

\section{ACKNOWLEDGEMENTS}

This work is done at "Unié de Développement des Equipements Solaires (UDES)" within the team "Application of Photovoltaic Equipment", the authors wish to acknowledge all those who contributed to its completion.

\section{REFERENCES}

[1] Alice Napoleon et al, "The Real Costs of Cleaning Up Nuclear Waste: A Full Cost Accounting of Cleanup Options for the West Valley Nuclear Waste Site", Technical Report of Synapse Energy Economics, Inc, November 2008: available at www.synapse-energy.com.

[2] Dr. J. Abdul Jaleel et al, "Simulation on Maximum Power Point Tracking of the Photovoltaic Module using LabVIEW", International Journal of Advanced Research in Electrical, Electronics and Instrumentation Engineering, 2012, 1 (3), 190-199.

[3] M. Abdulkadir et al, "Modelling and simulation of a solar photovoltaic system, its dynamics and transient characteristics in LABVIEW", International Journal of Power Electronics and Drive System (IJPEDS), 2013, 3 (2), 185-192.

[4] D.T. Cotfas et al, "Methods to determine the dc parameters of solar cells: A critical review", Renewable and Sustainable Energy Reviews, 2013, 28, 588-596.

[5] Rick Bitter, Taqi Mhiuddin, Matt Nwrocki, "LabVIEW Advenced Programming Techniques", Second edition, CRC Press, Taylor \& Francis Group, 2006.

[6] Jiang Chao et al, "Design of Instrument Control System Based on LabVIEW", TELKOMNIKA Indonesian Journal of Electrical Engineering, 2013, 11 (6), 3427-3432.

[7] S. Vergura, E. Natangelo, "Labview interface for data analysis of PV plants", Proceeding IEEE International Conference on Clean Electrical Power (ICCEP), 2009, 236-241.

[8] H. Tian et al, "A cell-to-module-to-array detailed model for photovoltaic panels", Solar Energy, 2012, 86, 26952706.

[9] E. Karatepe, M. Boztepe, M. Çolak, "Development of a suitable model for characterizing photovoltaic arrays with shaded solar cells", Solar Energy, 2007, 81 (8), 977-992.

[10] J.C.H. Phang, D.S.H. Chan and J.R. Phillips. "Accurate analytical method for the extraction of solar cell model parameters", Electronics Letters, 1984, 20 (10), 406-408.

[11] W. De Soto, S.A. Klein, W.A. Beckman, "Improvement and validation of a model for photovoltaic array performance", Solar Energy, 2006, 80 (1), 78-88.

[12] G. Blaesser and E. Rossi, "Extrapolation of outdoor measurements of PV array I-V characteristics to standard test conditions", Solar Cells, 1988, 25, 91-96.

[13] Vicente Leite and Faustino Chenlo, "An Improved Electronic Circuit for Tracing the I-V Characteristics of Photovoltaic Modules and Strings", Proceeding of International Conference on Renewable Energies and Power Quality (ICREPQ'10) Granada (Spain), 2010.

[14] O.M. Midtgård and T.O. Sætre, "Seasonal variations in yield for different types of PV modules measured under real life conditions in northern Europe”, Proceeding 21st European Photovoltaic Solar Energy Conference, 2006, 2383-2386.

[15] A. Mahrane, A. Guenounou, Z. Smara, M. Chikh, M. Lakehal, “Test bench for Photovoltaic Modules”, Proceeding International Symposium on Environment Friendly Energies in Electrical Applications (EFEEA10), 2010.

[16] A. Mermoud, "Conception et Dimensionnement de Systèmes Photovoltaïques : Introduction des Modules PV en couches minces dans le logiciel PVsyst", Research report of the Institute for Environmental Sciences, University of Geneva, Switzerland, 2005 : available at : http://www.pvsyst.com 


\section{BIOGRAPHIES OF AUTHORS}
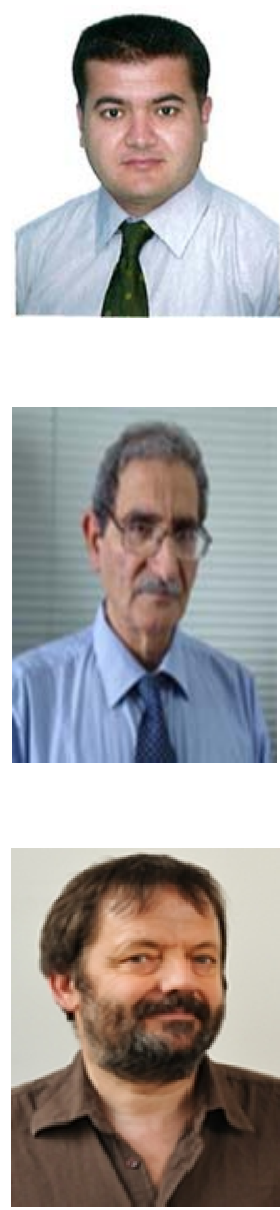

Michel Aillerie: Obtained a PhD in 1991 and the Habilitation to Lead Researches in 2001 at the Université Paul Verlaine of Metz, currently Université de Lorraine. He is Professor since 2005 and makes his research at the Laboratoire Materiaux Optiques et Photonique, LMOPS of the Universite de Lorraine and Centrale Supelec in Metz. His activities concern two main themes. The first one concerns the Characterization of functional non-linear optical, properties of materials for optoelectronic applications. The second one concerns "The development and optimization of energy production systems in renewable energy context". He is leader of the "Materials and Systems axis" and of the "Electrical Systems for Renewable Energies team" of the LMOPS. He collaborated in several national and international research projects. He is author of more than one hundred publications in international reviews with referees and in more than 120 international conference eproceedings (withs election on full text). He was invited as speaker in 25 international conferences and was editor of 4 publication revues.

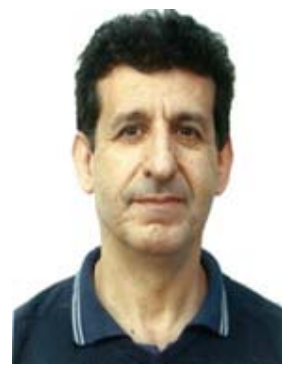

Achour Mahrane: Received his first Engineering degree in electronics from École Nationale Polytechnique (ENP) Algiers, Algeria, in 1982 and the DEA diploma in electronics from Paul Sabatier University, Toulouse, France, in 1990 then the Doctorate degree in 1994.

From 1985 to 1989 then 1995 to 2002, worked on the design and fabrication of solar modules and in the field of infrared sensors at the Unité de Développement de la Technologie du silicium (UDTS), Algiers, Algeria. Served as Research Associate from 2003 to 2004 and Assistant Professor from 2005 to 2006 at the Department of Electrical Engineering of the Ecole Polytechniquede Montreal, Canada. Moved to the Unité de Développement des Equipements Solaires (UDES), Bou Ismaill, Tipaza, Algeria in 2007. Currently, he is the director of the division of Renewable Energy Equipements and also involved in research and development in the areas of solar cells, solar modules, stand alone/on grid PV and BIPV systems, smart home and smart grid. 